\title{
KARAKTERISTIK BUAH DAN MUTU MORFO-FISIOLOGIS BENIH LONKIDA (Nauclea orientalis L.) DARI HABITAT ALAMI DI SULAWESI TENGGARA
}

Fruit and morpho-physiology seed Characteristics of Lonkida (Nauclea orientalis L.) from natural habitats in South East Sulawesi

\author{
Faisal Danu Tuheteru ${ }^{1}$, Cecep Kusmana ${ }^{2}$, Irdika Mansur ${ }^{2}$ dan Iskandar ${ }^{3}$ \\ 1) Program Studi Silvikultur, Fakultas Kehutanan Institut Pertanian Bogor dan \\ Jurusan Kehutanan Fakultas Kehutanan dan Ilmu Lingkungan, \\ Universitas Halu Oleo \\ Jl. Lingkar Akademik, Kampus IPB Darmaga, Bogor 16680 \\ 2) Departemen Silvikultur, Fakultas Kehutanan Institut Pertanian Bogor \\ Jl. Lingkar Akademik, Kampus IPB Darmaga, Bogor 16680 \\ 3) Departemen Ilmu Tanah dan Sumberdaya Lahan, Fakultas Pertanian \\ Institut Pertanian Bogor \\ Jl. Meranti, Kampus IPB Darmaga, Bogor 16680 \\ E-mail : faisaldanu_28@yahoo.com
}

\begin{abstract}
Lonkida (Nauclea orientalis L.) is a native multipurpose tropical tree species in Indonesia, which a few information regarding its biology and ecology. An experimental research was carried out to examine characters of fruit, seed and seed quality of lonkida growing at different habitat in South East Sulawesi. Fruit and seed was collected from four habitat types, such as dry land, permanent swamp, temporary swamp and temporary swamp savanna. The parameters to be observed were fruit size, seed size and morpho-physiology seed quality. The results showed that fruit size and number of seed per fruit are significantly different among habitats. The mean of fruit's length and width and number of seed per fruit originated from permanent swamp and temporary swamp is greater than that of fruit's from lonkida stand growing in the remain habitat's. Those parameters ranging from $4.99 \pm 0.17$ to $6.66 \pm 0.19 \mathrm{~cm}$ for fruit length and $3812 \pm 519$ to $13.984 \pm 1912$ seed for number of seed per fruit. Beside, the habitat condition also significantly affected to the characters of seed dimension and seed quality. Permanent swamp was a habitat with seed size and seed weight lower compare to another habitats. However, seeds produced by the lonkida stand growing on permanent swamp habitat and temporary swamp savanna has the higher percent of germination, germination capacity and mean day germination (MDG) than that of the seeds from lonkida stand growing on other habitats. Seed length is positively correlated with seed width and negative correlation with means germination time.
\end{abstract}

Key words : permanent swamp habitat, seed physiology quality, lonkida, Nauclea orientalis, seed length

\begin{abstract}
ABSTRAK
Lonkida (Nauclea orientalis L.) merupakan jenis pohon tropis multiguna yang tumbuh alami di Indonesia namun informasi biologi dan ekologinya masih sangat terbatas. Penelitian ini bertujuan untuk mengkaji karakter buah, biji dan mutu benih lonkida berasal dari beberapa
\end{abstract}


habitat di Sulawesi Tenggara. Koleksi buah dan biji dilakukan dari empat habitat yakni darat kering, rawa, rawa temporal dan savanna. Peubah yang diamati diantaranya ukuran buah dan biji serta mutu fisiologis benih lonkida. Hasil penelitian menunjukkan bahwa habitat berpengaruh signifikan $(\mathrm{P}<0,0001)$ terhadap peubah ukuran buah dan jumlah biji per buah. Habitat rawa dan rawa temporal memiliki rata-rata panjang buah, lebar buah serta jumlah biji per buah lebih tinggi dengan kisaran panjang buah 4,99 $\pm 0,17-6,66 \pm 0,19 \mathrm{~cm}$ dan jumlah biji per buah berkisar antara 3812 $\pm 519-13.984 \pm 1912$ biji. Selain karakter buah, habitat juga berpengaruh signifikan $(\mathrm{P}<0,0001)$ terhadap panjang biji, lebar biji dan berat biji serta mutu benih lonkida. Habitat rawa termasuk habitat dengan ukuran biji dan berat benih yang rendah dibanding habitat lainnya. Meskipun demikian, habitat rawa bersama habitat savanna memiliki persentase kecambah, daya kecambah dan rata-rata benih berkecambah per hari (MDG) yang tinggi. Panjang biji berkorelasi positif dengan berat biji $(\mathrm{P}>0,0008, \mathrm{r}=0,72)$ dan berkorelasi negatif terhadap rata-rata waktu untuk berkecambah (MGT) $(\mathrm{P}>0,011, \mathrm{r}=-0,70)$.

\section{Kata kunci : habitat rawa, mutu fisiologis benih, lonkida, Nauclea orientalis, panjang biji}

\section{PENDAHULUAN}

\section{Lonkida (Nauclea orientalis L.)} merupakan salah satu jenis pohon tropis yang multiguna, yaitu sebagai penghasil kayu untuk memenuhi kebutuhan industri perkayuan (Dayan et al., 2007), bahan obat (Lim 2013), serta sebagai tanaman untuk agroforestry, fitoremediasi dan rehabilitasi lahan terdegradasi khususnya lahan basah (Marghescu 2001; Amihan-Vega and Mendoza 2005; Mawaddah 2012). Jenis ini memiliki kisaran habitat yang luas, baik di ekosistem lahan basah diantaranya rawa (Ruxton et al., 1967), gambut (Kartikasari et al., 2012) dan hutan sepanjang aliran sungai (Johansen et al., 2007; Petty and Douglas 2010), maupun di lahan kering seperti savanah dan padang rumput (Ruxton et al.,1967). Selain itu jenis ini juga ditemukan mulai dari wilayah pantai sampai pada ketinggian 1400 m dpl (Ochse and Van Den brink 1977; Keßler et al., 2002).

Kisaran ekologi tersebut diduga akan berpengaruh terhadap produksi dan karakter buah dan biji serta mutu benih lonkida. Penelitian tentang karakter buah dan biji serta mutu benih tanaman hutan yang dipengaruhi oleh habitat masih terbatas (Ganatsas et al., 2008; Mataruga et al., 2010). Schmidt (2000) menyebutkan bahwa produksi dan karakter buah dan biji sangat dipengaruhi oleh lingkungan dan genetik. Beberapa aspek penting dari kedua faktor tersebut yang berkontribusi terhadap karakter buah dan biji (ukuran dan berat) diantaranya tegakan/pohon sumber benih (Mukassabi et al., 2012; Pollice et al., 2012), provenans/ geografis (Abasse 2011; Assogbadjo et al., 
2011), variasi genetik (Bilir et al., 2008; Rao et al., 2011) serta ketinggian tempat (Tewari et al., 2011; Wahid and Bounora 2012).

Perbedaan karakter buah dan biji tersebut juga akan berpengaruh terhadap perkecambahan, pertumbuhan dan survival bibit. Ukuran dan berat biji merupakan faktor utama yang mempengaruhi komponen penting perkecambahan (Shankar 2006; Loha et al., 2006), pertumbuhan dan daya hidup bibit (Parker et al., 2006; Cicek and Tilki 2007). Terdapat kecenderungan bahwa benih dengan ukuran besar dan berat yang cukup cenderung memiliki daya kecambah serta pertumbuhan dan daya hidup yang tinggi (Moegenburg 1996; Mandal et al., 2008; Sage et al., 2011).

Informasi budidaya jenis lonkida di Indonesia belum tersedia dan masih terbatas di wilayah Jawa Barat. Danu dkk. (2011) melaporkan buah lonkida yang berasal dari Banten dan Majalengka Provinsi Jawa Barat memiliki ukuran 4-5 cm dengan ukuran benih 1-1,5 mm. Jumlah benih sebanyak 5,5 juta butir per $\mathrm{kg}$ dengan kecambah sekitar 1500 per 5 gr benih (Kosasih dkk. 2011). Meskipun demikian, belum ada informasi karakterisasi buah dan biji serta mutu benih lonkida pada berbagai habitat di Sulawesi Tenggara. Dengan demikian, studi perbedaan habitat terhadap ukuran buah dan biji serta mutu benih lonkida perlu dilakukan.

$$
\text { Penelitian ini bertujuan untuk }
$$

mengkaji pengaruh perbedaan habitat terhadap karakter buah dan biji Lonkida, pengaruh perbedaan habitat terhadap mutu fisiologis benih lonkida, dan hubungan karakter biji dengan mutu benih dari sumber benih berbeda habitat.

\section{BAHAN DAN METODE}

\section{A. Waktu dan Tempat Penelitian}

Buah lonkida diperoleh dari pohonpohon induk berdasarkan perbedaan habitat yaitu rawa, rawa temporal, lahan darat kering dan savanna rawa temporal di 3 (tiga) Kabupaten/Kota di Sulawesi Tenggara (Kota Kendari, Kab. Konawe Selatan dan Kab. Konawe) (Gambar 1). Pengumpulan buah dilakukan saat akhir musim buah pada bulan Oktober 2012. Pengamatan bentuk dan pengukuran buah dan biji dilakukan di Laboratorium Kehutanan Universitas Halu Oleo, Kendari dan Laboratorium Anatomi Kayu, Litbang Kementerian Kehutanan, Bogor. Uji mutu fisiologis benih dilakukan di rumah kaca Departemen Silvikultur Fakultas Kehutanan IPB. Contoh tanah dianalisis di Laboratorium Tanah dan Tanaman SEAMEO 
BIOTROP, Bogor.

\section{B. Prosedur}

1. Eksplorasi buah lonkida dan pengambilan contoh tanah.

Buah lonkida dikoleksi dari pohonpohon induk hasil eksplorasi di Kota Kendari, Kab. Konawe dan Kab. Konawe Selatan Propinsi Sulawesi Tenggara (Sultra). Berdasarkan penelitian pendahuluan diperoleh 4 (empat) habitat lonkida yaitu rawa, rawa temporal, lahan darat kering dan savanna rawa temporal. Pengumpulan buah lonkida dilakukan dengan cara dipungut di lantai hutan dan dipanjat. Buah dikoleksi dari 23 pohon induk yang sedang berbuah diakhir musim berbuah dan dikelompokan berdasarkan empat habitat alami di Sultra.

Pengambilan contoh tanah ditentukan secara sengaja (purposive), dimana setiap lokasi yang mewakili tipe habitat tersebut diambil contoh tanahnya pada dua selang kedalaman yaitu 0-30 $\mathrm{cm}$ dan $30-60 \mathrm{~cm}$, dicampur merata tiap kedalaman dan kemudian contoh tanah diambil secara komposit seberat 5001000 gram untuk analisis sifat kimia dan fisik tanah (tekstur tanah).

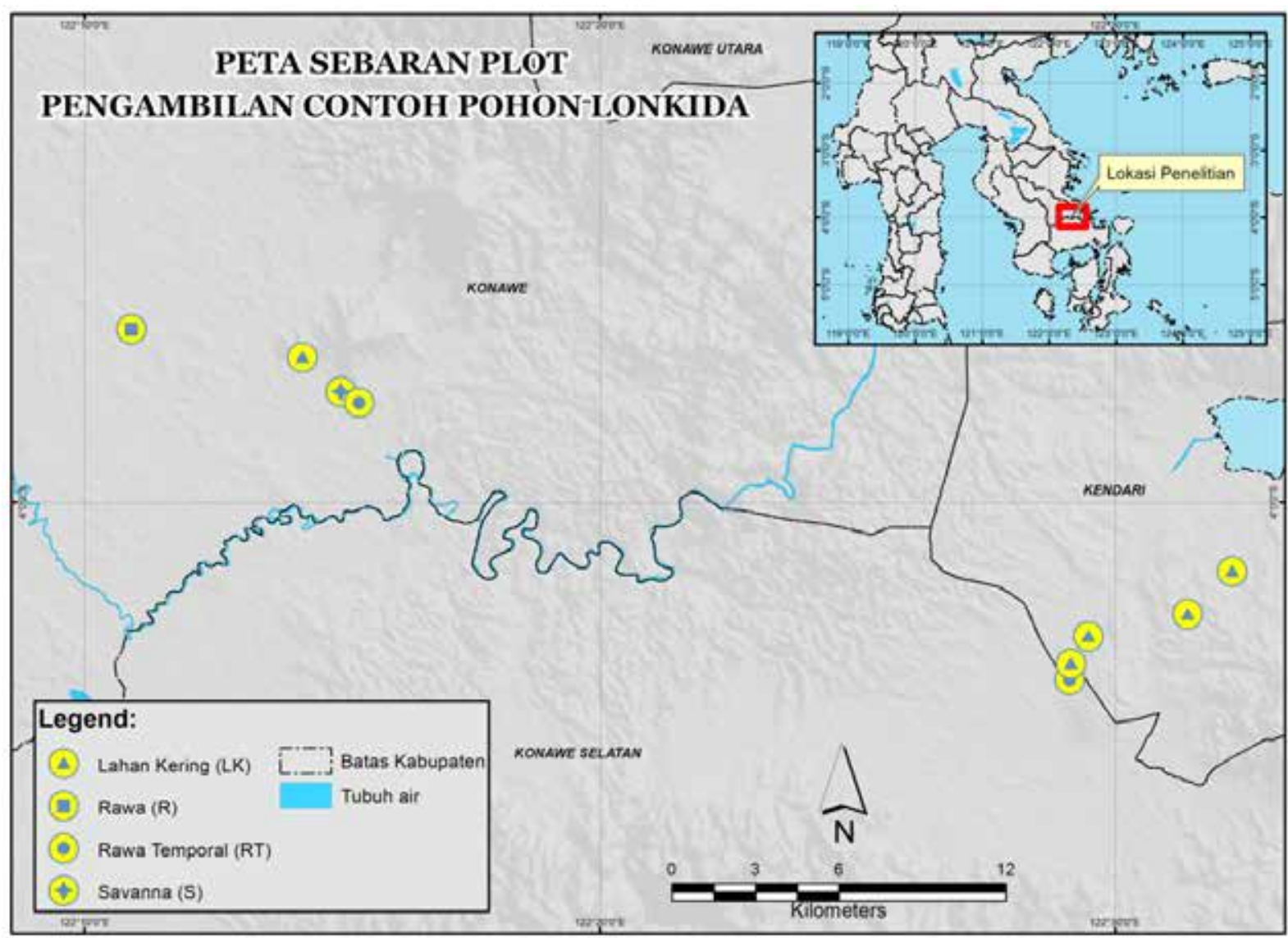

Gambar 1. Sebaran lokasi koleksi buah lonkida di beberapa habitat di Sulawesi Tenggara 


\section{Ekstraksi dan penyiapan benih.}

Buah diremas didalam ember berisi air dan diekstraksi menggunakan saringan teh pada air mengalir. Biji yang telah dikeringanginkan disimpan dalam kantong plastik. Benih yang digunakan sebagai contoh diperoleh secara acak dari lot benih masing-masing habitat. Setiap lot benih terdiri dari campuran $2 \mathrm{~g}$ benih setiap buah. Untuk kebutuhan perkecambahan benih tidak diberi perlakuan awal.

\section{Penyiapan media persemaian.}

Media yang digunakan untuk perkecambahan adalah pasir : arang sekam (1:1). Media disterilkan dengan cara disangrai selama \pm 2 jam, kemudian diletakkan di dalam kotak berbahan mika $(20 \times 20 \times 5 \mathrm{~cm})$ yang sudah dilubangi.

\section{E. Rancangan Penelitian}

Pengamatan ukuran buah, biji dan mutu fisiologis dilakukan menggunakan Rancangan Acak Lengkap (RAL) dengan perlakuan perbedaan habitat. Terdapat 4 (empat) habitat yaitu rawa, rawa temporal, lahan darat kering dan savanna rawa temporal. Khusus pengujian mutu fisiologis setiap perlakuan diulang 3 kali dengan setiap satuan percobaan digunakan 5 bak kecambah, dimana masing-masing terdiri atas 100 biji sehingga jumlah keseluruhannya adalah 1500 biji.

\section{F. Pengamatan}

Pengamatan dilakukan terhadap beberapa peubah, yaitu ukuran buah dan biji, berat benih 1000 butir, dan daya berkecambah. Sebanyak 40 buah dari masingmasing habitat (kecuali rawa temporal sebanyak 30 buah) diambil secara acak dan diukur dengan menggunakan kaliper digital pada kedua sisi buah. Sedangkan ukuran biji dilakukan dengan mengamati 30 biji dari masing-masing habitat dibawah mikrosokop stereo perbesaran 20x. Untuk pengamatan berat benih 1000 butir dilakukan dengan mengambil dan menghitung 100 benih dengan 8 ulangan secara acak. Kemudian menghitung koefisien keragaman dari berat 100 butir benih antara 8 ulangan tersebut. Jika koefisien keragaman (CV) lebih kecil dari 4,0 maka analisis diterima (Peraturan Dirjen RLPS No. P.13/V-PTH/2007). Sedangkan daya berkecambah (G) dilakukan dengan menghitung banyaknya benih yang mampu berkecambah hingga akhir pengamatan perkecambahan yang telah ditentukan (Hartman et al., 2002). Ratarata waktu untuk berkecambah (MGT) 
diukur berdasarkan rata-rata hari yang diperlukan untuk berkecambah, dengan persamaan : MGT $=\left\{\left(\sum(\right.\right.$ tini $) / \sum$ ni $\left.)\right\}$, $\sum($ tini $) / \sum$ ni $\left.)\right\}$, dimana $t$ adalah hari yang diperlukan untuk berkecambah (0) dan $\mathrm{n}=$ jumlah biji berkecambah pada akhir pengamatan (Hartman et al., 2002). Ratarata benih berkecambah per hari (MDG) diukur berdasarkan persamaan : $\mathrm{MDG}=$ $\mathrm{N} / \mathrm{t}$, dimana $\mathrm{N}$ adalah total jumlah biji yang berkecambah pada akhir pengamatan dan $\mathrm{t}$ adalah jumlah hari pengamatan (Hartman et al., 2002).

Untuk mengetahui pengaruh habitat alam terhadap karakteristik buah dan biji lonkida, dalam penelitian ini juga dilakukan pengamatan terhadap kondisi biofisik habitat alam. Beberapa kondisi biofisik yang diamati antara lain adalah jenis dan sifat fisik serta kimia tanah. $\mathrm{pH}$ (H2O dan CaCl2) menggunakan metode SNI 03-67872002, C organik [SNI 13-4720-1998(Walkey \& Black)], N Total [SNI 13-4721-1998 (Kjeldahl)], P2O5 [SL-MU-TT-05 (Bray I/ II), Kation-kation dapat ditukar (Ca, $\mathrm{Mg}, \mathrm{K}$, Na, KTK, KB) [SL-MU-TT-07 c (Ekstrak Penyangga NH4Oac 1,0 N pH 7,0)] dan tekstur tanah (SL-MU-TT-10).

\section{G. Analisis Data}

Data pengujian dianalisis menggunakan analisis ragam (ANOVA) yang jika nyata dilanjutkan dengan perbandingan rataan menggunakan uji Tukey. Data hubungan antara peubah dianalisis menggunakan analisis korelasi Pearson's. Data dianalisis menggunakan software SAS Portabel 9.1.3.

\section{HASIL DAN PEMBAHASAN}

\section{A. Sifat Kimia dan Fisik Tanah}

Hasil analisis sifat kimia dan fisik tanah menunjukkan bahwa lonkida tumbuh pada kondisi lahan dengan $\mathrm{pH}\left(\mathrm{H}_{2} \mathrm{O}\right)$ berkisar 4,8-6,1 (masam-agak masam) dengan tekstur tanah didominasi liat, kecuali tekstur lempung pada habitat lahan kering. C-organik termasuk rendah dan $\mathrm{N}$ tot sedang pada kedalaman 0-30 $\mathrm{cm}$ di habitat rawa, rawa temporal dan lahan kering. Kisaran C berkisar $0,20-1,92 \%$ dan $\mathrm{N}$ total $<0,5$ \%. $\mathrm{C} / \mathrm{N}$ rasio termasuk rendah dan sangat rendah dengan kisaran 3,3-6,9. Habitat rawa termasuk memiliki $\mathrm{P}$ tersedia yang rendah dan habitat lainnya termasuk sangat rendah (Tabel 1). 
Habitat lahan kering dengan bahan induk batuan ultramafik termasuk habitat dengan kandungan $\mathrm{Mg}$, Na, KTK dan KB yang sangat tinggi. Kandungan Ca berkisar antara 1,98-24,17 cmol/kg termasuk rendah sampai sedang. Kandungan $\mathrm{K}$ termasuk tinggi pada habitat savanna dengan kedalaman 0-30 cm $(0,82 \mathrm{cmol} / \mathrm{kg})$. Kandungan Mn pada tanah di semua habitat termasuk sangat tinggi dan menurun seiring dengan kedalaman tanah, kecuali pada habitat lahan kering dengan bahan induk batuan ultramafik. Rawa, rawa temporal dan savanna rawa temporal cenderung memiliki kandungan $\mathrm{Fe}$ total yang rendah pada kedalaman 30-60 cm, dibanding habitat lahan kering.

Tumbuhan lonkida banyak berkembang pada tiga jenis tanah yaitu inceptisols, alfisols dan oxisols. Inceptisols termasuk jenis tanah yang umum ditumbuhi lonkida. Jenis tanah inceptisols juga dilaporkan mendominasi jenis-jenis tanah yang ditumbuhi lonkida di Taman Nasional Rawa Aopa Watumohai, Sulawesi Tenggara (Tuheteru dan Alimuddin 2013). Alfisols ditemukan pada habitat lahan kering dengan bentuk lahan dataran tektonik dan bahan induk batupasir dan batuliat. Lonkida yang tumbuh di lahan kering dengan bantuk lahan intrusi volkan dan bahan induk berupa batuan ultramafik memiliki jenis tanah oxisols. Hardjowigeno (2010) menjelaskan bahwa tanah oxisols merupakan jenis tanah tua dengan kandungan liat tinggi dan banyak mengandung oksida-oksida besi atau oksida Al. Lebih lanjut dijelaskan habitat rawa, rawa temporal dan savanna memiliki bahan induk aluvium dengan bentuk lahan dataran aluvial sebagai penciri tanah inceptisols (Tabel 2).

\section{B. Karakteristik Buah dan biji lonkida}

Buah lonkida umumnya berbentuk bulat, baik beraturan maupun tidak beraturan. Buah yang masak dicirikan dengan warna buah coklat kekuningan. Tipe buah lonkida termasuk buah berdaging yang memiliki banyak biji. Perbedaan habitat berpengaruh nyata terhadap ukuran buah dan biji lonkida $(\mathrm{P}<0,05)$. Habitat rawa dan rawa temporal memiliki rata-rata ukuran buah yang lebih besar dibandingkan dua habitat lainnya (Tabel 3). Rata-rata ukuran buah (panjang dan lebar) berkisar antara 4,99 $\pm 0,17-6,66 \pm 0,19 \mathrm{~cm}$. Koefisien keragaman ukuran buah adalah 19\% dan $22 \%$ masing-masing untuk panjang dan lebar buah. Buah dengan ukuran besar umumnya memiliki jumlah benih yang banyak dan 
sebaliknya (Tabel 4). Tampak pada Tabel 3 bahwa terdapat variasi jumlah biji per buah $(\mathrm{P}<0,0006)$ dimana habitat savanna dan darat kering memiliki rata-rata jumlah benih lebih rendah dibanding habitat rawa dan rawa temporal. Rata-rata jumlah biji per buah berkisar $3899 \pm 355-13.984 \pm 1912$ biji/ buah dan koefisien keragaman adalah 96\%. Meskipun, habitat savanna memiliki ukuran buah dan jumlah benih yang rendah tetapi memiliki ukuran benih lebih besar $(\mathrm{P} / \mathrm{L}$ rasio 2,29) dari habitat lainnya. Rata-rata panjang benih dari habitat savanna sebesar 1,35 mm, sedangkan habitat rawa memiliki rata-rata panjang benih terrendah sebesar 0,99 mm (Tabel 3 dan Gambar 2). Koefisien keragaman ukuran biji adalah $3 \%$ dan $2 \%$ untuk panjang dan lebar biji.

Hasil penelitian di atas menunjukkan bahwa terdapat variasi ukuran buah, biji dan mutu benih dari pohon lonkida yang tumbuh pada habitat yang berbeda. Secara umum, panjang buah dan lebar buah lebih besar dijumpai pada habitat rawa dan rawa temporal. Hal yang sama juga ditemukan pada peubah jumlah biji per buah. Namun demikian, ukuran buah lonkida yang ditemukan di habitat rawa memiliki panjang dan lebar biji yang rendah. Keberadaan koefisien keragaman $(\mathrm{CV}=96 \%)$ pada peubah jumlah biji per buah mengindikasikan bahwa pengaruh lingkungan sangat kuat, sedangkan nilai $\mathrm{KK}$ rendah $(\mathrm{CV}=2-3 \%)$ pada peubah panjang dan lebar memberikan indikasi biji lebih banyak dikontrol oleh pengaruh genetik (Kimmins 1987).

Variasi buah dan biji yang terjadi pada pohon lonkida diduga disebabkan perbedaaan habitat yang berinteraksi dengan elemen-elemen genetik. Mkonda et al., (2003) melaporkan bahwa variasi morfologi dan bobot benih selain dipengaruhi oleh faktor lingkungan juga dikontrol oleh faktor genetik. Loha et al., (2006) menjelaskan perbedaan ukuran biji tidak hanya diwariskan tetapi juga sangat dipengaruhi oleh variasi lingkungan.

Kemungkinan faktor habitat yang berkontribusi terhadap variasi buah dan jumlah biji per buah adalah ketersediaan air selama proses perkembangan buah (Loha et al., 2006). Selain itu, pembentukan buah sangat dikaitkan dengan alokasi karbon hasil fotosintesis (Bazzaz et al., 2000) dimana bahan utama fotosintesis adalah air. Kozlowski and Pallardy (1997) menjelaskan bahwa perkembangan buah sangat tergantung pada mobilisasi karbohidrat 
hasil fotosintesis dan ketersediaan air. Lebih lanjut, ukuran buah berkurang seiring dengan defisit air tanaman sebelum dan sesudah periode pembuahan. Pengambilan buah pada penelitian ini dilakukan pada musim kemarau, sehingga diduga ketidakcukupan air pada habitat lahan kering. Pengaruh ketersediaan air juga dilaporkan pada jenis Manilkara kauki (L.) (Sudrajat dan Megawati 2010). Pada penelitian ini, jumlah biji terbanyak cenderung ditemukan pada buah yang lebih besar. Hal ini sejalan dengan hasil penelitian pada Faidherbia albida (Dangasuk et al., 1997), Balanites aegyptiaca (Abbase et al., 2011) dan Strychnos cocculoides (Mkonda et al., 2003).

Panjang dan lebar biji, selain dipengaruhi oleh habitat juga dipengaruhi oleh genetik $(\mathrm{CV}=2-3 \%)$. Panjang dan lebar biji serta berat benih lebih rendah pada habitat rawa dibanding habitat lainnya, meskipun habitat rawa memiliki buah yang besar. Setiap jenis memiliki strategi tertentu antara memproduksi benih kecil dalam jumlah banyak dibandingkan sedikit benih dengan ukuran besar. Strategi jenis tersebut sangat dikaitkan dengan alokasi fotosintat untuk tujuan reproduksi dan seleksi terhadap cekaman (Leishmen et al., 2000). Menurut
Loha et al., (2008) dan Assogbadjo et al., (2011) bahwa ukuran biji sangat dipengaruhi oleh pohon induk. Selain pohon induk, posisi benih dalam buah/pohon dan umur tanaman juga diduga memberikan kontribusi (faktor ini tidak diamati). Wahid and Bounoua (2012) melaporkan bahwa, perbedaan kondisi lingkungan selama perkembangan biji dan kombinasinya dengan variabilitas genetik juga dapat mempengaruhi ukuran biji. 


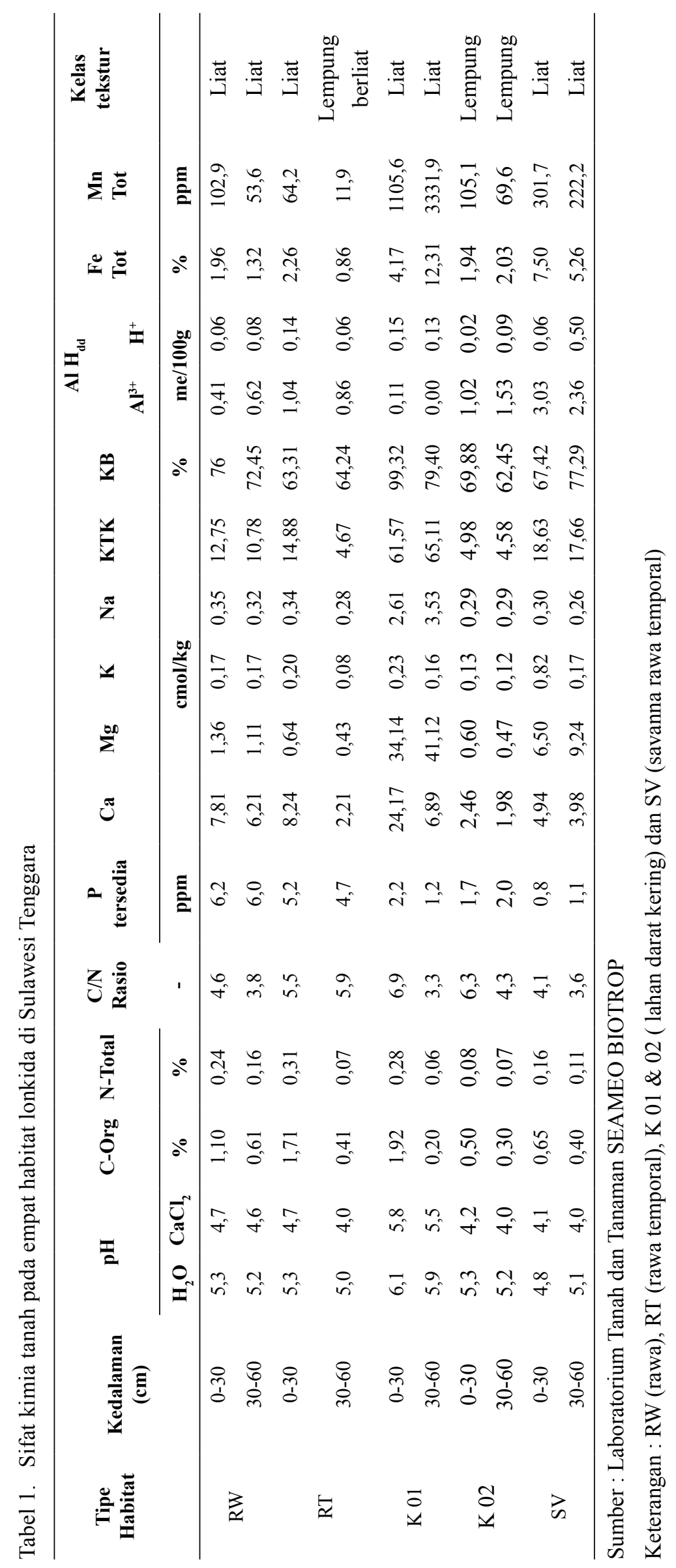


Tabel 2. Data tanah pada habitat lonkida berdasarkan peta tanah tingkat tinjaus 1:250.000 Provinsi Sulawesi Tenggara

\begin{tabular}{|c|c|c|c|c|c|c|c|}
\hline $\begin{array}{c}\text { Unit } \\
\text { Lahan }\end{array}$ & $\begin{array}{l}\text { Bentuk } \\
\text { Lahan }\end{array}$ & $\begin{array}{l}\text { Bahan } \\
\text { Induk }\end{array}$ & Relief & $\begin{array}{c}\text { Le- } \\
\text { reng } \\
(\%) \\
\end{array}$ & $\begin{array}{c}\text { Klasifikasi tanah } \\
\text { (soil taxonomy, } \\
\text { 2010) } \\
\end{array}$ & Proporsi & Habitat \\
\hline Au13fo & $\begin{array}{l}\text { Dataran } \\
\text { aluvial }\end{array}$ & Aluvium & Datar & $0-1$ & $\begin{array}{l}\text { Typic Endoaquepts } \\
\text { Vertic } \\
\text { Endoaquepts } \\
\text { Fluventic } \\
\text { Eutrudepts } \\
\text { Typic Haplustepts }\end{array}$ & $\begin{array}{l}\mathrm{F}^{*} \\
\mathrm{~F} \\
\mathrm{M} \\
\mathrm{M}\end{array}$ & $\begin{array}{l}\text { Rawa, rawa } \\
\text { temporal, } \\
\text { savanna, lahan } \\
\text { darat kering }\end{array}$ \\
\hline Tgf11no & $\begin{array}{l}\text { Dataran } \\
\text { tektonik }\end{array}$ & $\begin{array}{l}\text { Batupasir, } \\
\text { batuliat }\end{array}$ & Agak datar & $1-3$ & $\begin{array}{l}\text { Ustic Dystrudepts } \\
\text { Typic Haplustepts } \\
\text { Typic Eutrudepts } \\
\text { Typic Endoaquepts }\end{array}$ & $\begin{array}{l}\mathrm{F} \\
\mathrm{F} \\
\mathrm{M} \\
\mathrm{M}\end{array}$ & $\begin{array}{l}\text { lahan darat } \\
\text { kering }\end{array}$ \\
\hline Tgf11u2 & $\begin{array}{l}\text { Dataran } \\
\text { tektonik }\end{array}$ & $\begin{array}{l}\text { Batupasir, } \\
\text { batuliat }\end{array}$ & Berombak & $3-8$ & $\begin{array}{l}\text { Typic Haplustalfs } \\
\text { Typic Eutrudepts } \\
\text { Typic Haplustepts } \\
\text { Vertic } \\
\text { Endoaquepts }\end{array}$ & $\begin{array}{l}\mathrm{F} \\
\mathrm{F} \\
\mathrm{M} \\
\mathrm{M}\end{array}$ & $\begin{array}{l}\text { lahan darat } \\
\text { kering }\end{array}$ \\
\hline Tgf11r2 & $\begin{array}{l}\text { Dataran } \\
\text { tektonik }\end{array}$ & $\begin{array}{l}\text { Batupasir, } \\
\text { batuliat }\end{array}$ & $\begin{array}{l}\text { Bergelom- } \\
\text { bang }\end{array}$ & $8-15$ & $\begin{array}{l}\text { Typic Haplustalfs } \\
\text { Ultic Haplustalfs } \\
\text { Typic Haplustepts } \\
\text { Typic Endoaquepts }\end{array}$ & $\begin{array}{l}\mathrm{F} \\
\mathrm{F} \\
\mathrm{M} \\
\mathrm{M}\end{array}$ & $\begin{array}{l}\text { lahan darat } \\
\text { kering }\end{array}$ \\
\hline Vs4no & $\begin{array}{l}\text { Intrusi } \\
\text { volkan }\end{array}$ & $\begin{array}{l}\text { Batuan } \\
\text { ultramafik }\end{array}$ & Agak datar & $1-3$ & $\begin{array}{l}\text { Typic Acrudox } \\
\text { Typic Hapludox } \\
\text { Typic Eutrudepts } \\
\text { Typic Endoaquepts }\end{array}$ & $\begin{array}{l}\mathrm{F} \\
\mathrm{F} \\
\mathrm{M} \\
\mathrm{M}\end{array}$ & $\begin{array}{l}\text { lahan darat } \\
\text { kering }\end{array}$ \\
\hline
\end{tabular}

Keterangan: $\mathrm{F}=$ fair $(25-49 \%)$ dan $\mathrm{M}=$ minor $(10-24 \%)$

Sumber: Peta Tanah Tingkat tinjau skala 1:250.000 Provinsi Sulawesi Tenggara.

Balai Besar Penelitian Dan Pengembangan Sumberdaya Lahan Pertanian (BBSDLP) Tahun 2011 


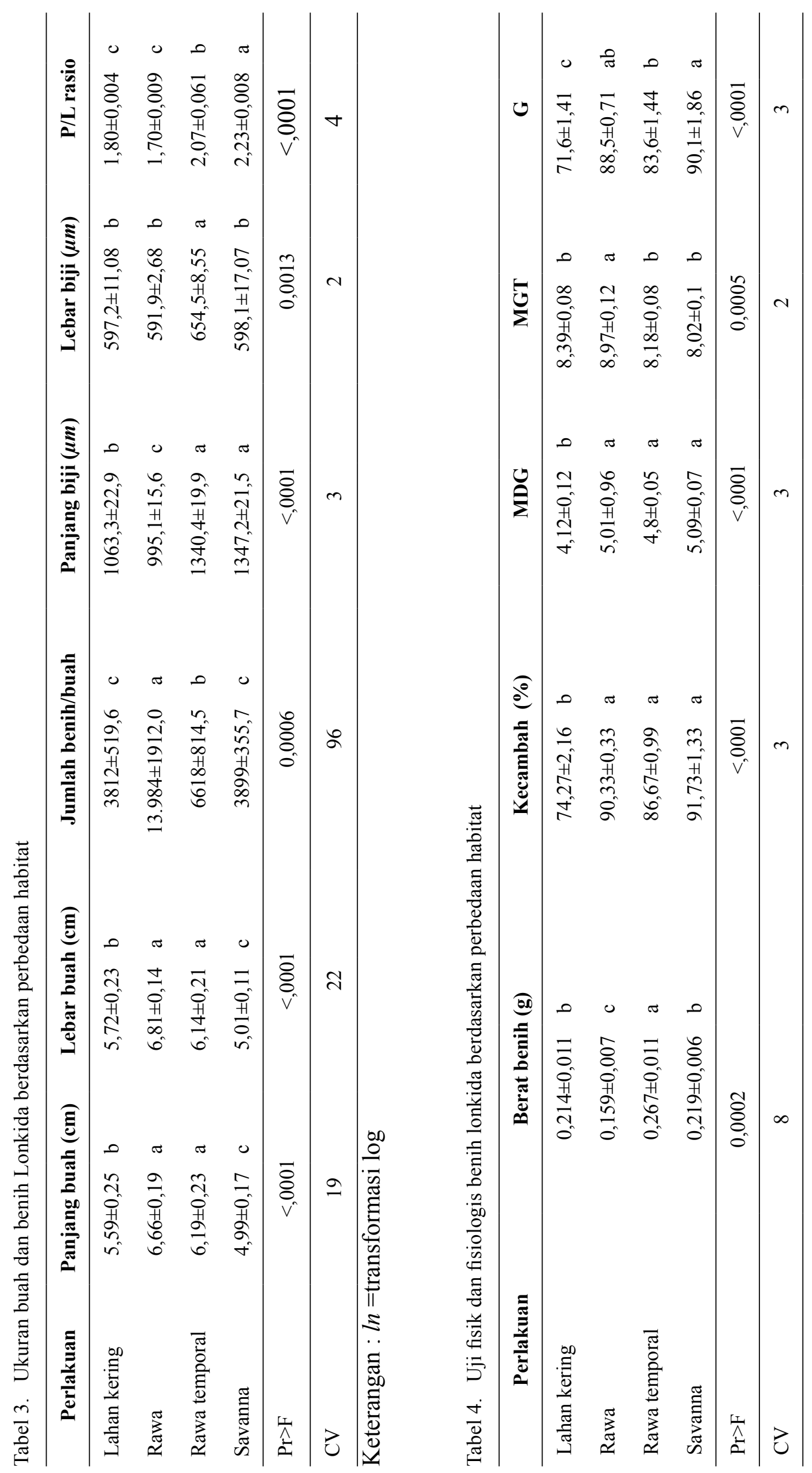


Menurut Leishmen et al., (2000) bahwa ukuran dan bentuk biji sebagai dasar tingkat adaptasi dan strategi jenis. Benih yang berat cenderung lebih adaptif terhadap kondisi kering (Leishmen et al., 2000; Wahid and Bounoua, 2012). Hasil telaah Leishmen et al., (2000) menunjukkan bahwa, terdapat hubungan antara benih besar dengan daerah kering dan tanah dengan kesuburan tanah rendah. Lebih lanjut, benih ukuran kecil cenderung dihasilkan pada kondisi tergenang, sedangkan pada daerah kering tumbuhan menghasilkan benih ukuran besar pada jenis yang sama. Hasil penelitian Munthali et al., (2012) menunjukkan bahwa ukuran benih Adansonia digitata L. lebih kecil di daerah dengan curah hujan tinggi dibanding daerah dengan curah hujan rendah. Terkait dengan sifat tanah, Leishmen et al., (2000) menyimpulkan bahwa tidak ditemukan hubungan antara ukuran biji dengan kesuburan tanah.

Pada penelitian ini ukuran buah berkisar 4,99-6,66 x 5,01-6,81 cm dan ukuran biji 0,995-1,347 x 0,59-0,65 mm. Ukuran buah dan biji hampir sama dengan ukuran buah dan biji lonkida yang dilaporkan di Australia (Boland et al., 2006) dan Banten dan Majalengka (Danu $d k k$. 2011) serta di
Taman Nasional Wasur, Papua (La Hisa $d k k$. 2012). Kesamaan ukuran biji lonkida pada sebaran alaminya menunjukkan bahwa ukuran biji lebih dipengaruhi oleh faktor genetik tanaman lonkida.

\section{Mutu morfo-fisiologis benih lonkida}

Hasil analisis ragam menunjukkan bahwa habitat berpengaruh signifikan terhadap mutu benih lonkida $(\mathrm{P}<0,001)$ (Tabel 4). Hasil penelitian menunjukkan bahwa habitat rawa temporal memiliki berat 1000 butir lebih besar $(0,267 \pm 0,011 \mathrm{~g})$ diikuti oleh darat kering dan savanna. Panjang benih berkorelasi positif dengan berat benih 1000 butir dan berkorelasi negatif dengan peubah MGT (Tabel 5). Ukuran benih (rasio panjang dan lebar benih) berkorelasi positif dengan kecepatan berkecambah, MDG dan daya berkecambah (G). Perkecambahan terjadi mulai lima hari setelah penaburan (Gambar 3) dan tingkat perkecambahan diatas $50 \%$ terjadi pada hari ke-8. Perkecambahan ditandai dengan munculnya plumula. Habitat memberikan pengaruh signifikan terhadap persentase perkecambahan $(\mathrm{P} \leq 0,0001)$. Persentase perkecambahan dan daya kecambah tertinggi pada habitat savanna $(91,73 \pm 1,33 \%$ dan $90,1 \pm 1,86 \%)$ dan rawa $(90,3 \pm 0,33 \%$ dan $88,5 \pm 0,71 \%)$ dan habitat 
darat kering lebih rendah $(74,27 \pm 2,16 \%$ dan $71,6 \pm 1,41 \%)$. Pada peubah MGT, ratarata hari tercepat pada habitat savanna $(8,02 \pm 0,1$ hari) dan tertinggi pada habitat rawa $(8,97 \pm 0,12$ hari). Pada peubah MDG tertinggi dijumpai pada habitat savanna dan rawa dan terendah pada habitat darat kering $(4,12 \pm 0,12$ benih). Secara umum koefisien keragaman $(\mathrm{CV})$ semua peubah mutu benih berkisar antara $2-8 \%$.

Benih dengan ukuran lebih panjang memberikan pengaruh positif terhadap peningkatan berat 1000 butir benih $(\mathrm{r}=0,72)$. Hasil penelitian ini menunjukkan bahwa berat benih sangat dipengaruhi oleh panjang benih. Penelitian ini sejalan dengan hasil penelitian pada jenis Cordia africana
(Loha et al., 2006) dan Trigonobalanus doichangensis (Zheng et al., 2009), Namun demikian, panjang benih dan berat benih berkorelasi negatif terhadap peubah MGT dan tidak ditemukan korelasi kuat antara kedua peubah itu terhadap persentase kecambah dan daya berkecambah benih lonkida. Tidak adanya korelasi ukuran benih dan berat benih dengan persentase kecambah juga dilaporkan pada benih Eucalyptus delegatensis (Close and Wilsan, 2002) dan Pinus pinaster (Wahid and Bounoua, 2012). Meskipun hasil penelitian lain melaporkan adanya korelasi positif antara ukuran benih dengan perkecambahan pada Prunus cerasoides (Tewari et al., 2011).
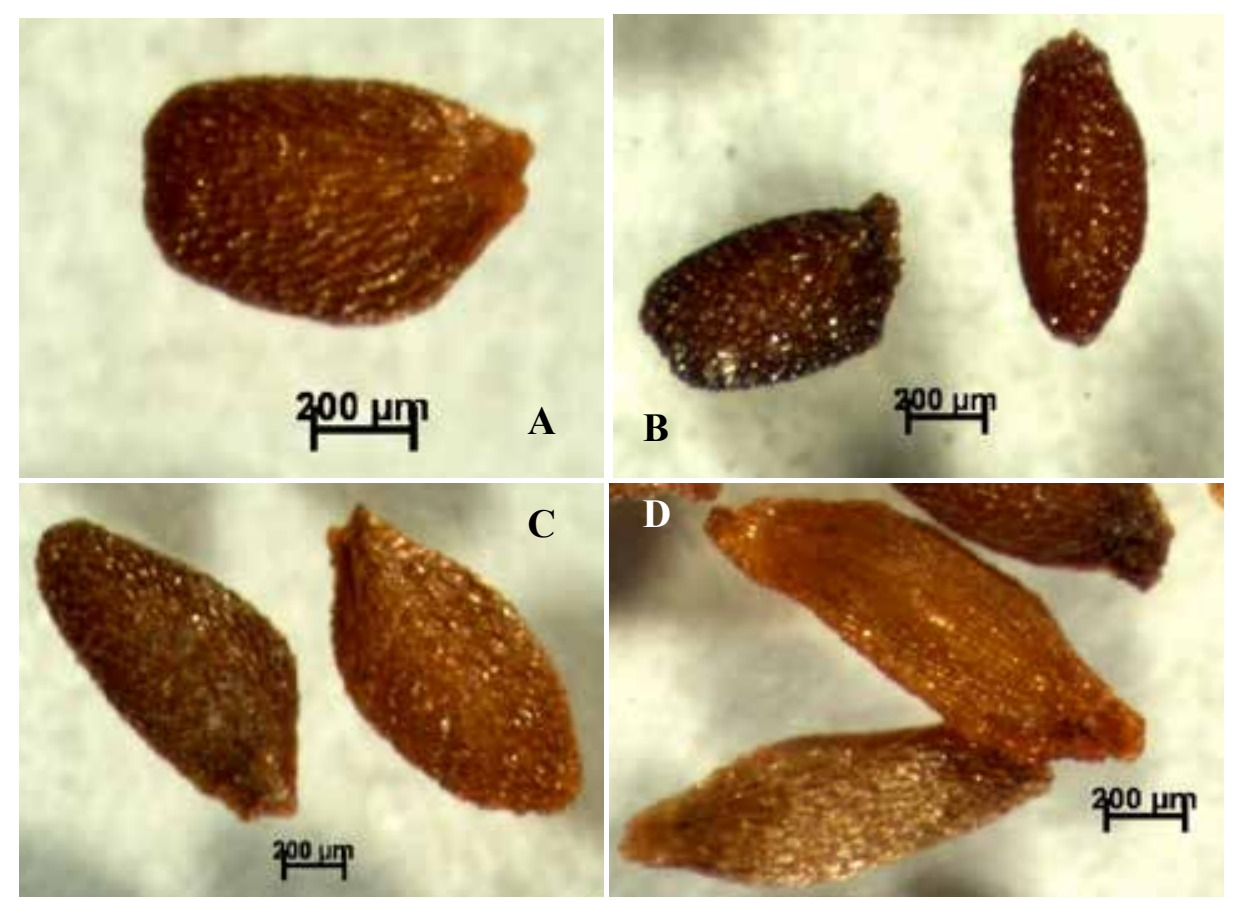

Gambar 2. Bentuk dan ukuran biji lonkida, $\mathrm{A}=$ darat kering, $\mathrm{B}=$ rawa, $\mathrm{C}=$ rawa temporal dan $\mathrm{D}=$ savanna). Perbesaran 20x 
Tabel 5. Korelasi antar peubah pengamatan

\begin{tabular}{lccccccc}
\hline & $\begin{array}{c}\text { Panjang } \\
\text { biji }\end{array}$ & $\begin{array}{c}\text { Lebar } \\
\text { biji }\end{array}$ & Kecambah & MDG & MGT & G & Berat benih \\
\hline Panjang biji & - & 0,05 & 0,338 & 0,338 & $-0,819$ & 0,320 & 0,722 \\
Lebar biji & & - & $-0,115$ & $-0,115$ & $-0,469$ & $-0,023$ & 0,050 \\
Kecambah & & & - & 1 & 0,009 & 0,989 & $-0,111$ \\
MDG & & & & - & 0,009 & 0,989 & $-0,111$ \\
MGT & & & & & - & 0,033 & $-0,701$ \\
G & & & & & - & $-0,173$ \\
Berat benih & & & & & & & - \\
\hline
\end{tabular}

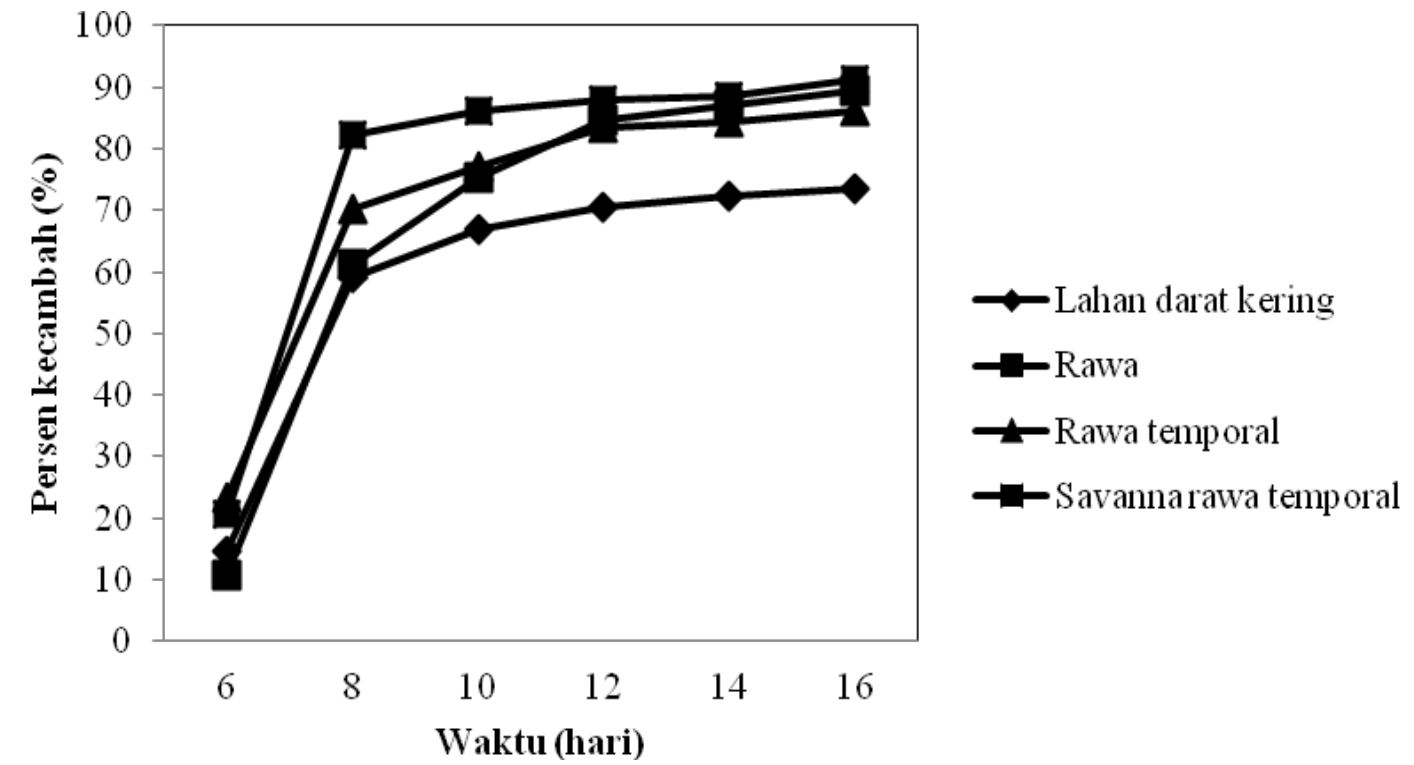

Gambar 3. Perkecambahan benih lonkida yang dikoleksi dari habitat berbeda

Variasi perkecambahan benih lonkida juga ditemukan pada penelitian ini. Variasi perkecambahan benih berdasarkan perbedaan habitat alami juga ditemukan pada jenis Pinus pinaster (Wahid and Bounoua 2012), Pinus nigra (Mataruga et al., 2010), Manilkara kauki (L.) (Sudrajat dan Megawati 2010). Persentase kecambah benih lonkida dari habitat lahan kering lebih rendah $(\mathrm{P} \leq 0,0001)$ dibanding habitat lainnya. Perbedaan tersebut diduga karena benih dari lahan darat kering cenderung memiliki kadar air yang rendah dan memiliki dormansi fisik sehingga dapat menghambat perkecambahan benih. Assogbadjo et al., (2011) melaporkan benih Adansonia digitata L. dari zona yang relatif kering dan panas memiliki daya kecambah yang rendah. Hal yang sama dilaporkan pada jenis Pinus nigra dari habitat berbatu dan kering dibandingkan habitat suboptimal 
(Mataruga et al., 2010). Benih Pinus nigra dari populasi Maroko Selatan (wilayah kering) memiliki daya kecambah rendah dibanding habitat lainnya.

\section{KESIMPULAN}

Hasil penelitian menunjukkan bahwa lonkida dapat tumbuh pada empat habitat alami di Sulawesi Tenggara. Perbedaan habitat alami tersebut berpengaruh terhadap variasi ukuran buah, biji dan mutu benih lonkida. Ukuran buah dan jumlah benih per buah ditemukan lebih tinggi pada habitat rawa dan rawa temporal. Namun demikian, habitat rawa memiliki panjang benih, lebar benih dan berat 1000 butir benih lebih rendah dibanding habitat lainnya. Habitat rawa dan savanna termasuk habitat yang memiliki mutu benih lonkida yang baik, dimana persentase kecambah lebih dari $90 \%$ dengan rata-rata benih berkecambah diatas 5 benih/hari. Secara umum, variasi morfologi buah dan biji serta mutu benih lonkida sangat dipengaruhi oleh perbedaan ekotipe (variasi tipe habitat) dan genetik.

\section{DAFTAR PUSTAKA}

Abasse, T., Weber, J.C., Katkore, B., Boureima, M., Larwanou, M., dan Kalinganire A., 2011. Morphological Variation in Balanites aegyptiaca Fruits and Seeds Within and Among Parkland Agroforests in Eastern Niger. Agrofor. Syst., 81:5766.
Alam, M.A., Matin, M.A., Hoque, M.M., dan Hoque A.T.M.K., 2005. Seed Morphology and Germination of IpilIpil (Leocaena leococephala (Lam.) De Wit.) Under Different Conditions at Nursery Stage in Bangladesh. Asian Journal of Plant Sciences, 4(2):98-101

Amihan-Vega, B., dan Mendoza. JD., 2005. Benefits from Tree Growing in the Degraded Uplands: Empirical Realities from Tabango, Leyte, The Philippines. In Harrison, S., Herbohn, J., Suh, J., Mangaoang E., and Vanclay, J., (editors). Proceedings from the End-ofproject Workshop Held in Ormoc city, The Philipines; 19-21 August 2004; Filipina. pp93-106.

Assogbadjo, A.E., Kaka, R.G., Edon, S., Kyndt, T., dan Sinsin, B., 2011. Natural Variation in Fruit Characteristics, Seed Germination and Seedling Growth of Adansonia digitata L. in Benin. New For., 41:113-125.

Bazzaz, F.A., David, D.A., dan Reekie, E.D., 2000. Reproductive Allocation in Plants, dalam Fenner, M. (ed), The Ecology of Regeneration in Plant Communities, $2^{\text {nd }}$ edition. CAB International, New York. pp1-30

Bilir, N., Finnvid P., Lindgren, Dag., dan Kroon, J., 2008. Variation in Cone and Seed Characters in Clonal Seed Orchards of Pinus sylvestris. New For., 36:187-199.

Boland, D.J., Brooker, M.I.H., Chippendale, G.M., Hall, N., Hyland, B.P.M., Johnston, R.B., Kleinig, D.A., McDonals, M.W., dan Turner, J.D., 2006. Forest Trees of Australia. Australia: CSIRO. $768 \mathrm{p}$

Cicek, E., dan Tilki, F., 2007. Seed Size on Germination, Survival and Seedling Growth of Castanea sativa Mill. Journal of Biological Science, 7(2):438-441.

Close, D.C., dan Wilson, S.J., 2002. Provenance Effect on Pre-germination Treatments for Eucalyptus regnans and E. delegatensis Seed. For. Ecol. Manage., 170:299-305.

Dangasuk, O.G., Seurei, P., dan Gudu, S., 1997. Genetic Variation in Seed and Seedling Traits in 12 African Provenances of Faidherbia albida (Del.) A. Chev. at Lodwar, Kenya. Agrofor. Syst., 37:133141. 
Danu., Nurochim, N., dan Haerujaman, AH., 2011. Mengenal Pohon Gempol (Nauclea orientalis L.) di Jawa Barat dan Banten. Info benih, 15(2):55-59.

Dayan, M.dP., Rosalinda, S.R., dan Bandian, D.B., 2007. Indigenous Forest Tree Species in Laguna Province. DENR Recommends Vol 15b. 25p

Ganatsas, P., Tsakaldimi, M., dan Thanos, C., 2008. Seed and Cone Diversity and Seed Germination of Pinus pinea in Strofylia Site of the Natura 2000 Network. Biodivers Conservation, 17:2427-2439.

Hardjowigeno, S., 2010. Ilmu Tanah. Akademika Pressindo. Jakarta. pp208-234

Hartman, H.T., Kester, D.E., Davies, F.T., dan Geneve, R., 2002. Plant propagation: Principle and Practices. ${ }^{\text {th }}$ Ed. PrenticeHall International, Inc, New Yersey. $880 \mathrm{p}$

Johansen, K., Phinn, S., Dixon, I., Douglas, M., dan Lowry, J., 2007. Comparison of Image and Rapid Field Assessments of Riparian Zone Condition in Australian Tropical Savannas. For. Ecol. Manage., 240:42-60.

Kartikasari, S.N., Marshal, A.J., dan Beehler, B.M., 2012. Ekologi Papua. Seri Ekologi Indonesia. Jilid VI. Yayasan Pustaka Obor Indonesia dan Conservation International. Jakarta. 981p

Keßler, P.J.A., Bos, M.M., Daza, S.E.C.S., Kop, A., Willemse, L.P.M., Pitopang, R., dan Gradstein, S.R., 2002. Checklist of Woody Plants of Sulawesi, Indonesia. Blumea Supplement 14. National Herbarium Nedereland, Universiteit Leiden branch. $160 \mathrm{p}$

Kimmins, J.P., 1987. Forest Ecology: a Foundation for Sustainable Management, ${ }^{2 \mathrm{nd}}$. MacMillian Publishing Company, United States of America. 596p.

Kosasi, E., Ana, E., dan Safari, A. 2011. Gempol (Nauclea orientalis L.). Informasi singkat Benih No. 118 Agustus 2011. Balai Perbenihan Tanaman Hutan Jawa dan Madura. http://bpthbalinusra.net/ images/ISB/nauclea\%20orientalis.pdf. Doanload: 7 Maret 2012.

Kozlowski, T.T., dan Pallardy, S.G., 1997. Growth Control in Woody Plant. Academic Press, San Diego. pp166-193
La Hisa, Anwar, S., dan Suprajitno, A., 2012. Pengenalan Jenis Tumbuhan Berkayu di Taman Nasional Wasur. Balai Taman Nasional Wasur. Merauke. 157p.

Leishman, M.R., Wright, I.J., Moles, A.T., dan Westoby, M., 2000. The Evolutionary Ecology of Seed Size. dalam Fenner, M. (ed), The Ecology of Regeneration in Plant Communities, $2^{\text {nd }}$ edition. CAB International, New York. pp31-58.

Lim, T.K., 2013. Edible Medicinal and NonMedicinal Plants:Volume 5, Fruits. Springer, New York. pp754-757.

Loha, A.M., Tigabu dan Teketay, D., 2008. Variability in Seed- and Seedling-related Traits of Millettia ferruginea, a Potential Agroforestry Species. New For, 36:6778.

Loha, A.M., Tigabu., Demel, T., Lundkvist, K., dan Fries, A., 2006. Provenance Variation in Seed Morphometric Traits, Germination, and Seedling Growth of Cordia Africana Lam. New For., 32:7186.

Mandal, S.M., Chakraborty, D., dan Gupta, K., 2008. Seed Size Variation: Influence on Germination and Subsequent Seedling Performance in Hyptis suaveolens (Lamiaceae). Research Journal of Seed Science, 1(1):26-33.

Marghescu, T., 2001. Restoration of Degraded Forest Land in Thailand: The Case of Khao Kho. Unasylva, 207 (52):52-56.

Mataruga, M., Haase, D.L., dan Isajev, V., 2010. Dynamics of Seed Imbibition and Germination of Austrian pine (Pinus nigra Arnold) from Extreme Habitat Conditions Within Five Balkan Provenances. New For., 40:229-242

Mawaddah, M., 2012. Pertumbuhan Kayu Putih (Melaleuca leucadendron Linn.) dan Longkida (Nauclea orientalis Linn.) pada Kondisi Tergenang Air Asam Tambang [Skripsi]. Bogor (ID): Institut Pertanian Bogor. 32p.

Mkonda, A., Lungu, S., Maghembe, J.A., dan Mafongoya, P.L., 2003. Fruit- and Seed-Germination Characteristics of Strychnos cocculoides an indigenous 
fruit tree from natural populations in Zambia. Agrofor. Syst., 58:25-31.

Moegenburg, S.M., 1996. Sabal palmetto Seed Size: Causes of Variation, Choices of Predators, and Consequences for Seedlings. Oecologia, 106:539-543.

Mukassabi, T.A., Polwart, A., Coleshaw, T., dan Thomas P.A., 2012. Scots Pine Seed Dynamics on a Waterlogged Site. Trees, 26:1305-1315.

Munthali, C.R.Y., Chirwa, P.W., dan Akinnifesi, F.K., 2012. Phenotypic Variation in Fruit and Seed Morphology of Adansonia digitata L. (baobab) in Five Selected Wild Populations in Malawi. Agrofor. Syst., 85:279-290.

Ochse, J.J., dan Van Den Brink, R.C.B., 1977. Vegetables of the Dutch east Indies (edible tubers, bulbs, rhizomes and spices included). A. Asher \& Co. Bv. Amesterdam. 1005p.

Parker, W.C., Noland, T.L., dan Morneault, A.E., 2006. The Effects of Seed Mass on Germination, Seedling Emergence, and Early Seedling Growth of Eastern White Pine (Pinus strobus L.). New For., 32:33-49.

Peraturan Dirjen Rehabilitasi Lahan dan Perhutanan Sosial Nomor : P. 13 /V-PTH/2007 Tentang Petunjuk Teknis Pengujian Mutu Fisik Fisiologi Benih

Petty, A.M., dan Douglas, M.M., 2010. Scale Relationships and Linkages Between Woody Vegetation Communities Along a Large Tropical Floodplain River, North Australia. Journal of Tropical Ecology, 26:79-92.

Pollice, J., Marcora, P., dan Renison, D., 2012. Seed Production in Polylepis australis (Rosaceae) as Influenced by Tree Size, Livestock and Interannual Climate Variations in the Mountains of Central Argentina. New For., 44(2):233-247.

Rao, G.R., Shanker, A.K., Srinivas, I., Korwar, G.R., dan Venkateswarlu,
B., 2011. Diversity and Variability in Seed Characters and Growth of Pongamia pinnata (L.) Pierre accessions. Trees, 25:725-734.

Ruxton, B.P., Haantjens, H.A., Paijmans, K., dan Saunders, J.C., 1967. Lands of the Safia-Pongani Area, Territory of Papua and New Guinea. Land Research Series No. 17. Commonwealth Scientific and Industrial Research Organization, Australia. Melbourne. 217p.

Sage, R.D., Koenig, W.D., dan McLaughlin, B.C., 2011. Fitness Consequences of Seed Size in the Valley Oak Quercus lobata Née (Fagaceae). Annals of Forest Science, 68:477-484.

Schmidt, L., 2002. Pedoman Penanganan Benih Tanaman Hutan tropis dan Sub tropis 2000. Dirjen Rehabilitasi Lahan dan Perhutanan Sosial, Departemen kehutanan. Jakarta. $530 \mathrm{p}$.

Shankar, U., 2006. Seed Size as a Predictor of Germination Success and Early Seedling Growth in 'Hollong' (Dipterocarpus macrocarpus Vesque). New For., 31:305-320.

Singh, B., Bhatt, B.P., dan Prasad, P., 2006. Variation in Seed and Seedling Traits of Celtis australis, a Multipurpose Tree, in Central Himalaya, India. Agrofor. Syst., 67:115-122.

Sudrajat DJ dan Megawati. 2010. Keragaman morfologi dan respon perlakuan pra perkecambahan benih dari lima populasi sawo kecik (Manilkara kauki (L.) Dubard), Jurnal Penelitian Hutan Tanaman, 7(2):67-76.

Tewari, B., Tewari, A., Shah, S., Pande N., dan Singh, RP., 2011. Physical Attributes as Indicator of Seed Maturity and Germination Enhancement in Himalayan Wild Cherry (Prunus cerasoides D. Don.). New For., 41:139-146.

Tuheteru, F.D., dan Alimuddin, L.D., 2013. Ekologi dan Budidaya Lonkida (Nauclea orientalis L) 
yang berpotensi tanaman obat dan Fitoremediasi di Sulawesi Tenggara. Laporan Hibah Bersaing Tahun 2013, Lembaga Penelitian Universitas Halu Oleo. Kendari. 78p.

Wahid, N., dan Bounoua, L., 2012. The Relationship Between Seed Weight, Germination and Biochemical Reserve. New For., 44(3):385-397.
Zheng, Y.L., Sun, W.B., Zhou, Y., dan Coombs, D., 2009. Variation in seed and seedling traits among natural populations of Trigonobalanus doichangensis (A. Camus) Forman (Fagaceae), a rare and endangered plant in Southwest China. New For., 37:285-294. 